Pacific Northwest

National Laboratory Operated by Battelle for the
U.S. Department of Energy

\title{
Montana Slab Edge Insulation Analysis for 2006 IECC Adoption
}

K. Gowri, Ph.D.

March 2007

Prepared for

U.S. Department of Energy

under Contract DE-AC05-76RL01830 


\section{DISCLAIMER}

This report was prepared as an account of work sponsored by an agency of the United States Government. Neither the United States Government nor any agency thereof, nor Battelle Memorial Institute, nor any of their employees, makes any warranty, express or implied, or assumes any legal liability or responsibility for the accuracy, completeness, or usefulness of any information, apparatus, product, or process disclosed, or represents that its use would not infringe privately owned rights. Reference herein to any specific commercial product, process, or service by trade name, trademark, manufacturer, or otherwise does not necessarily constitute or imply its endorsement, recommendation, or favoring by the United States Government or any agency thereof, or Battelle Memorial Institute. The views and opinions of authors expressed herein do not necessarily state or reflect those of the United States Government or any agency thereof.

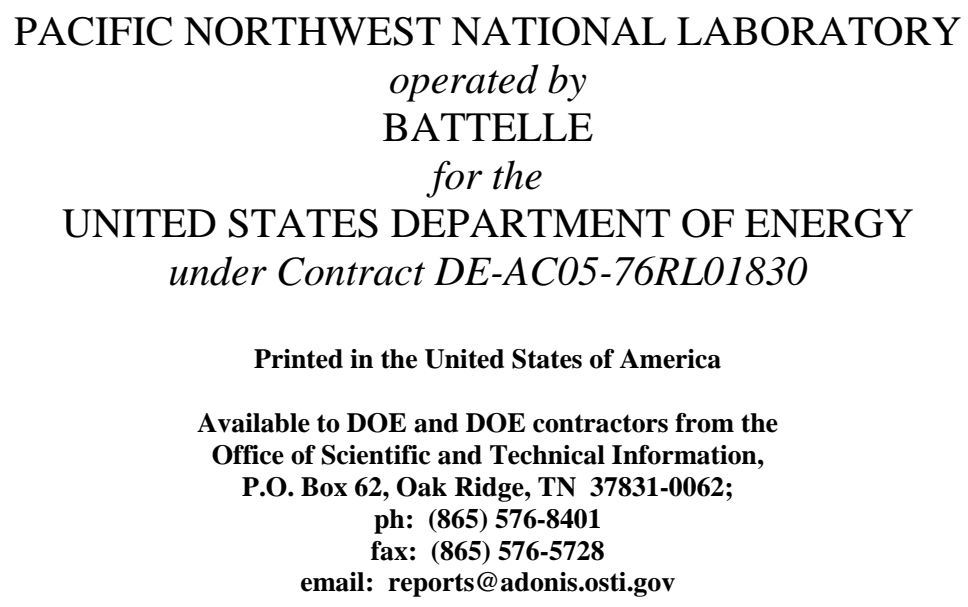

Available to the public from the National Technical Information Service, U.S. Department of Commerce, 5285 Port Royal Rd., Springfield, VA 22161 ph: (800) 553-6847 fax: (703) 605-6900

email: orders@ntis.fedworld.gov online ordering: http://www.ntis.gov/ordering.htm 


\title{
Montana Slab Edge Insulation Analysis for 2006 IECC Adoption
}

\author{
K. Gowri, Ph.D.
}

March 2007

Prepared for

the U.S. Department of Energy

under Contract DE-AC05-76RL01830

Pacific Northwest National Laboratory

Richland, Washington 99352 


\section{Summary}

At the request of the Montana Energy Office, the U.S. Department of Energy's (DOE's) Building Energy Codes Program (BECP) ${ }^{1}$ undertook an analysis of the energy savings associated with slab insulation in small commercial buildings.

The state of Montana is considering the adoption of IECC 2006. The current Montana energy code (based on IECC 2003) requires insulation for unheated slabs and belowgrade walls whereas in IECC 2006, for Montana climate zone 6, there are no such insulation requirements. The Montana Energy Office is concerned with the removal of existing slab insulation requirements if IECC 2006 were adopted without any amendments. In this study, several slab insulation configurations were analyzed to determine the energy and cost impact of the slab insulation requirement.

The results of this analysis show that slab edge insulation (R-10, 4-ft depth) results in savings of about $3 \%$ net annual site energy and $1-2 \%$ of annual energy cost in small retail and office buildings in Montana. The local practice of insulating the slab footing on the interior allows heat loss along the slab perimeter and thus does not achieve the full savings that could be achieved with full edge insulation configurations, but the savings are still significant.

\footnotetext{
${ }^{1}$ Pacific Northwest National Laboratory (PNNL) is funded by the U.S. DOE to perform this work. PNNL is managed by Battelle Memorial Institute under DOE Contract DE-AC05-76RL01830.
} 


\section{Contents}

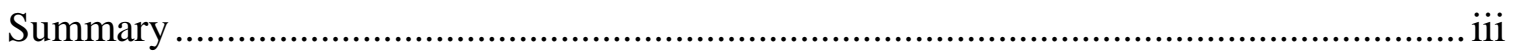

1. Energy Analysis of Slab Insulation Alternatives ................................................... 1

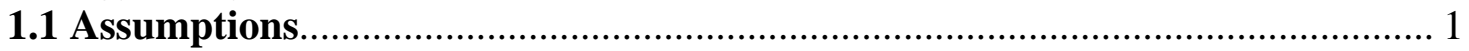

1.1.1 Simulation Model................................................................................... 1

1.1.2 Baseline Building Characteristics ......................................................... 1

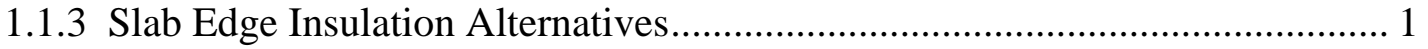

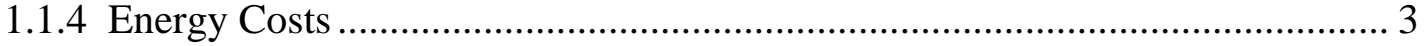

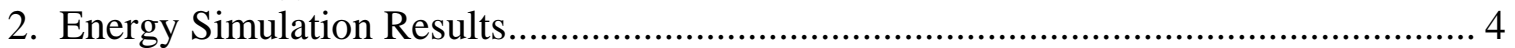

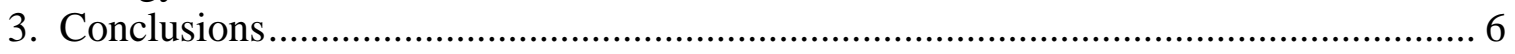

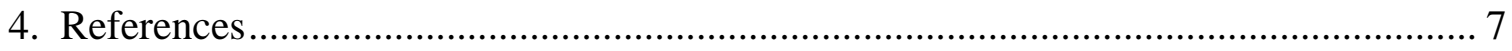




\section{Energy Analysis of Slab Insulation Alternatives}

The annual energy consumption for two small commercial buildings was calculated for several different slab edge insulation configurations.

\subsection{Assumptions}

The modeling assumptions, building characteristics and analysis details are provided below.

\subsubsection{Simulation Model}

Energy simulation for this study was done using eQUEST, Version 3.0 (Hirsch \& Associates 2006). eQUEST uses a DOE-2.2 hourly simulation engine to calculate building energy use for all 8760 hours in a year. The baseline building models were developed using the eQUEST Schematic Design Wizard. The baseline model building characteristics represent current practice in Montana, as described in the following section. Standard occupancy schedules and default equipment performance curves were used in this simulation.

\subsubsection{Baseline Building Characteristics}

The Montana Energy Office staff was consulted in choosing the building types, typical construction practices and building characteristics for the energy simulations. A small office building and a small retail commercial building (gas station, convenience store with dining area) were chosen, with the building characteristics, envelope and mechanical system details as presented in Table 1. The buildings are assumed to be single story, located in Helena, Montana with a heating-degree-day (HDD65) of 8031 and cooling-degree-day (CDD50) of 1922. The baseline buildings are assumed to represent current common construction practice in Montana and do not necessarily meet the prescriptive requirements in IECC 2006. The building envelope consists of a metal joist roof with R-30 cavity insulation below the deck, and concrete block exterior walls with perlite core and R-11 interior insulation in metal studs. The window-to-wall ratio is assumed to be $40 \%$, with windows equally distributed along the four facades. Double-glazed low-E windows with U-factors and solar heat gain coefficient (SHGC) (as shown in Table 1) were assumed for the simulations. Though the current construction practice includes installation of insulation along slab perimeter, the baseline building model was developed with no slab edge insulation to reflect the IECC 2006 requirement and several slab insulation configurations were analyzed as described in the following section.

\subsubsection{Slab Edge Insulation Alternatives}

Typical slab-on-grade construction in Montana is to insulate the interior of the slab footings along the perimeter, as shown in Figure 1. This configuration does not provide a thermal break between the footing and the slab edge. The recommended construction practices described in Table 4-1 of the Oak Ridge National Laboratory (ORNL) Builder's Foundation Handbook (ORNL 1991) and energy simulation programs in general assume slab-on-grade interior insulation with a thermal break along the slab edge. Hence, the energy analysis for this report was done assuming installation of thermal breaks for interior insulation configurations. 
Table 1: Building Characteristics for Energy Simulation

\begin{tabular}{|c|c|c|}
\hline General Building Info & Office & Gas station/retail \\
\hline Floor area & $5,400 \mathrm{ft}^{2}$ & $5,400 \mathrm{ft}^{2}$ \\
\hline Number of stories & 1 & 1 \\
\hline Shape & Rectangular & Rectangular \\
\hline Length & $90 \mathrm{ft}$ & $90 \mathrm{ft}$ \\
\hline Width & $60 \mathrm{ft}$ & $60 \mathrm{ft}$ \\
\hline Window-to-wall ratio & $40 \%$ & $40 \%$ \\
\hline \multicolumn{3}{|l|}{ Envelope Characteristics } \\
\hline $\begin{array}{c}\text { Wall type } \\
\text { Wall U-factor }\end{array}$ & $\begin{array}{c}\text { Concrete Masonry Wall } \\
\text { (insulated core) } \\
0.061 \mathrm{Btu} / \mathrm{h}-\mathrm{ft}^{2}{ }^{\circ} \mathrm{F} \\
(\mathrm{R}-11)\end{array}$ & $\begin{array}{c}\text { Concrete Masonry Wall } \\
\text { (insulated core) } \\
0.061 \mathrm{Btu} / \mathrm{h}-\mathrm{ft}^{2}{ }^{\circ} \mathrm{F} \\
(\mathrm{R}-11)\end{array}$ \\
\hline $\begin{array}{c}\text { Roof -type } \\
\text { Roof R-value }\end{array}$ & $\begin{array}{c}\text { Built up } \\
0.039 \text { Btu/h- } \mathrm{ft}^{2}-{ }^{\circ} \mathrm{F} \\
(\mathrm{R}-30)\end{array}$ & $\begin{array}{c}\text { Built up } \\
0.039 \text { Btu/h- } \mathrm{ft}^{2}{ }^{\circ} \mathrm{F} \\
(\mathrm{R}-30) \\
\end{array}$ \\
\hline $\begin{array}{l}\text { Window U-factor } \\
\text { (centre of glass) }\end{array}$ & 0.486 & 0.486 \\
\hline Window SHGC & 0.73 & 0.73 \\
\hline \multicolumn{3}{|l|}{ Lighting System } \\
\hline Lighting power density & $1.18 \mathrm{w} / \mathrm{ft}^{2}$ & $1.43 \mathrm{w} / \mathrm{ft}^{2}$ \\
\hline \multicolumn{3}{|l|}{ Mechanical System } \\
\hline Cooling system & $\begin{array}{l}\text { Packaged Single Zone } \\
\text { System (EER 9.5) }\end{array}$ & $\begin{array}{l}\text { Packaged Single Zone } \\
\text { System DX (EER 9.5) }\end{array}$ \\
\hline Heating system & Gas furnace (AFUE 78) & Gas furnace (AFUE 78) \\
\hline
\end{tabular}

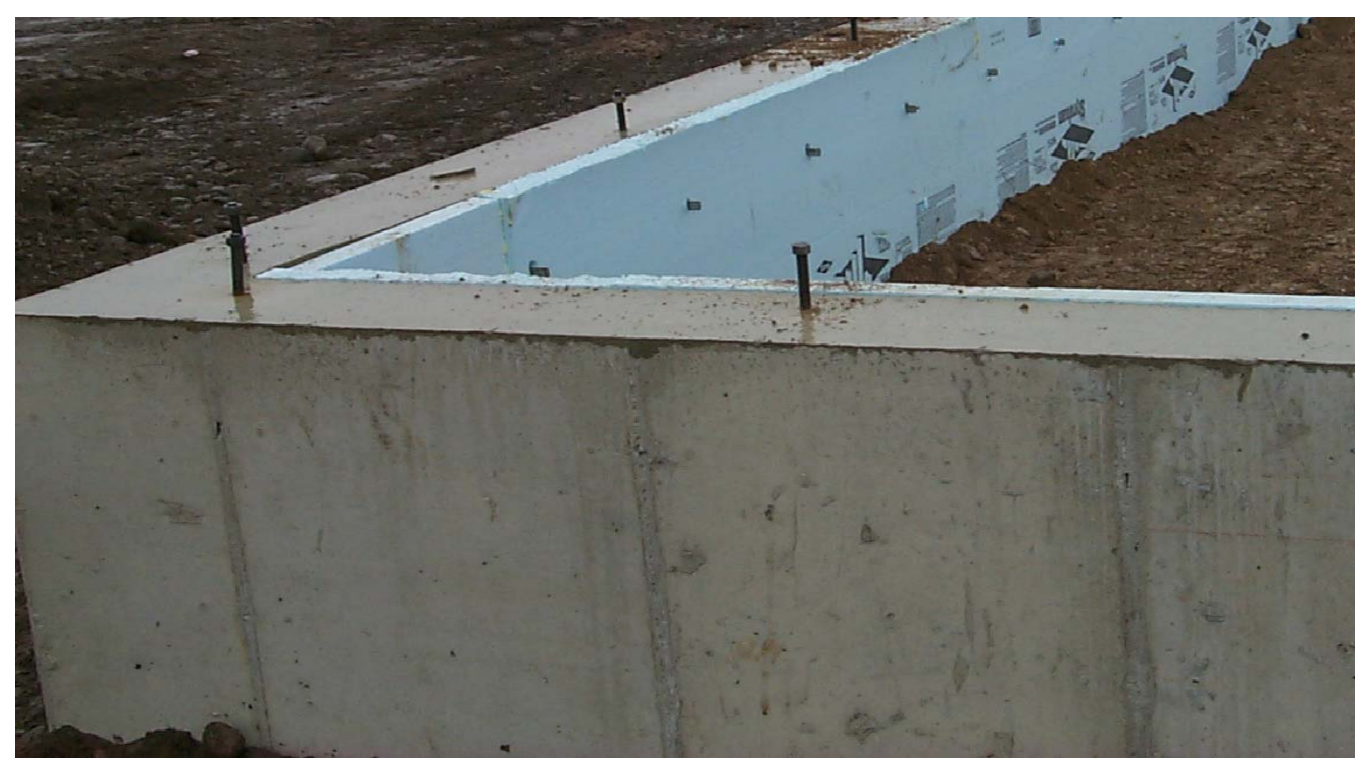

Figure 1: Typical Slab Insulation Installation 
The following four slab-on-grade insulation configurations were taken from Table 4-1 of ORNL Builder's Foundation Handbook (ORNL 1991), which provides recommendations on insulation levels and installation details (as shown in Figure 2):

1. Vertical insulation, interior of the foundation wall (R-10, 4-ft depth)

2. Vertical insulation, exterior of the foundation wall (R-10, 4-ft depth)

3. Horizontal insulation under the slab w/wrapped slab edge (R-10, 4-ft depth)

4. Full depth insulation under the slab (R-10).

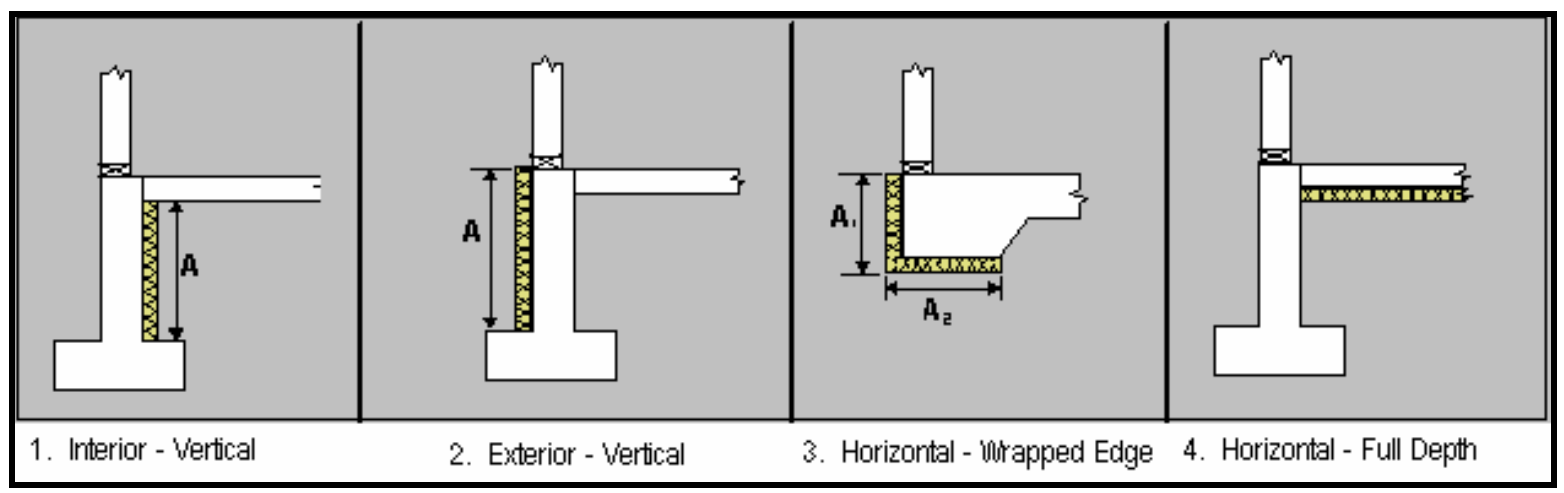

Figure 2: Slab Insulation Configurations

\subsubsection{Energy Costs}

To calculate annual energy costs, an average fuel cost of $\$ 0.087 / \mathrm{kWh}$ for electric and $\$ 0.99 /$ therm for natural gas were assumed, based on rates for a major utility in Montana NorthWestern Energy (NorthWestern Energy Corporation 2006). 


\section{Energy Simulation Results}

Table 2 presents the annual total energy consumption and annual energy costs for the two building types and four slab configurations. The relative energy and cost savings compared to the baseline building are also included in Table 2.

Table 2: Annual Energy Consumption and Cost Savings

\begin{tabular}{|c|c|c|c|c|c|c|c|c|}
\hline Slab Insulation Option & $\begin{array}{c}\text { Annual } \\
\text { Electric } \\
\text { (kWh) }\end{array}$ & $\begin{array}{l}\text { Annual } \\
\text { Nat. Gas } \\
\text { (Therms) }\end{array}$ & $\begin{array}{c}\text { Total } \\
\text { Energy } \\
\text { (kBtulyr) }\end{array}$ & $\begin{array}{l}\text { Energy } \\
\text { Savings } \\
\text { (kBtulyr) }\end{array}$ & $\begin{array}{c}\text { Energy } \\
\text { Savings } \\
(\%)\end{array}$ & $\begin{array}{l}\text { Annual } \\
\text { Energy } \\
\text { Cost (\$) } \\
\end{array}$ & $\begin{array}{c}\text { Annual } \\
\text { Energy } \\
\text { Savings } \\
(\$)\end{array}$ & $\begin{array}{c}\text { Annual } \\
\text { Cost } \\
\text { Savings } \\
(\%) \\
\end{array}$ \\
\hline \multicolumn{9}{|l|}{ Office Building } \\
\hline Uninsulated Slab & 46,356 & 1,489 & 307 & NA & NA & $\$ 5,618$ & NA & NA \\
\hline Vertical Interior R-10, $4 \mathrm{ft}$ & 47,041 & 1,354 & 296 & 11 & 3.6 & $\$ 5,522$ & $\$ 96$ & 1.7 \\
\hline Vertical Exterior R-10, $4 \mathrm{ft}$ & 47,091 & 1,344 & 295 & 12 & 3.9 & $\$ 5,514$ & $\$ 104$ & 1.9 \\
\hline Horizontal R-10, $4 \mathrm{ft}$ & 46,955 & 1,371 & 297 & 10 & 3.2 & $\$ 5,533$ & $\$ 85$ & 1.5 \\
\hline Fully Insulated R-10 & 47,259 & 1,310 & 292 & 15 & 4.8 & $\$ 5,489$ & $\$ 129$ & 2.3 \\
\hline \multicolumn{9}{|l|}{ Retail Building } \\
\hline Uninsulated Slab & 106,950 & 9,118 & 1,277 & NA & $N A$ & $\$ 18,332$ & NA & $N A$ \\
\hline Vertical Interior R-10, $4 \mathrm{ft}$ & 108,268 & 8,701 & 1,240 & 37 & 2.9 & $\$ 18,033$ & $\$ 299$ & 1.6 \\
\hline Vertical Exterior R-10, $4 \mathrm{ft}$ & 108,363 & 8,670 & 1,237 & 40 & 3.1 & $\$ 18,011$ & $\$ 321$ & 1.8 \\
\hline Horizontal R-10, $4 \mathrm{ft}$ & 108,098 & 8,754 & 1,244 & 32 & 2.5 & $\$ 18,071$ & $\$ 261$ & 1.4 \\
\hline Fully Insulated R-10 & 108,699 & 8,567 & 1,228 & 49 & 3.8 & $\$ 17,939$ & $\$ 393$ & 2.1 \\
\hline
\end{tabular}

In office buildings, insulating slab edges with R-10 vertical insulation for $4 \mathrm{ft}$ on the interior of the foundation wall results in savings of $3.6 \%$ or $11 \mathrm{kBtu} / \mathrm{hr}$ net total site energy. The net energy saving is realized through a $10 \%$ reduction in heating energy and $2 \%$ increase in cooling energy due to the reduction in heat loss through the slab edge. At current fuel prices, this amounts to a net savings of $\$ 96 /$ year or $1.7 \%$ of total energy cost. The same R-10 insulation installed $4 \mathrm{ft}$ horizontally under the slab results in slightly lower level of energy savings ( $0.4 \%$ less) and cost savings ( $0.2 \%$ less) compared to the interior vertical insulation. Insulating the slab edge vertically on the exterior results in slightly higher energy saving ( $0.3 \%$ better) and cost savings $(0.2 \%$ better) compared to the interior vertical insulation. Highest energy and cost savings are realized when the slab is fully insulated horizontally under the slab.

The percentage of energy and cost savings in small retail buildings is almost the same as that of office buildings. However, the total annual energy consumption in small commercial retail buildings is significantly higher because of occupancy type and schedule (assuming 24-hr operation of the convenience store and the dining area open year around). Typical interior vertical insulation (R-10, 4-ft depth) of slab edges can lower the annual energy cost by $\$ 299$. 
All four different slab edge insulation configurations in both buildings were found to save energy and reduce energy cost. Although this study did not undertake detailed first cost or life cycle analysis, a simple payback period can be estimated using slab edge insulation cost of $\$ 4.00$ per lineal foot of R-10 (4-ft wide) installed. This cost represents an average of $\$ 0.75+\$ 0.25$ per sq.ft. of insulation material and labor cost obtained from four local Montana builders. The total insulation installation cost for the buildings used in this study is approximately $\$ 1,200$. In commercial office buildings with vertical interior insulation, the payback period is estimated to be 12 years and for small commercial retail buildings the payback period is 4 years, assuming current energy prices prevail for the estimated period and no adjustments for inflation or financing costs.

The Montana Energy Office indicated that the local common practice is to install insulation on the interior side of slab footing without extending the insulation to the top edge of the slab (as shown in Figure 1) and requested that the impact of this practice on the overall energy savings be calculated. The energy impact of the lack of slab edge insulation could not be directly calculated because of limitations in modeling the slab edge details using eQUEST. Current research on-going at the University of Colorado ${ }^{2}$ indicates that the energy loss in small office buildings due to the thermal bridging effect caused by not insulating the edge of the slab is approximately $20 \%$ of all the foundation heat loss, and the ORNL study indicates that the loss could be up to $40 \%$ in residential construction. Assuming a 25\% reduction in slab edge insulation energy savings from this practice, the annual net energy savings for interior vertical insulation would be $\$ 72$ in small office buildings and $\$ 225$ in small retail buildings. These reductions could significantly affect the payback period; however, the overall energy reduction at the building level will be less than $1 \%$ because the slab edge insulation is approximately 3 to $4 \%$ of the total energy consumption of the building. This study has focused on evaluating the slab insulation configurations and has not analyzed the impact of insulation requirements for below-grade walls.

\footnotetext{
${ }^{2}$ Personal communication with M. Krarti, University of Colorado, 2007.
} 


\section{Conclusions}

This study shows that insulating slab edges with R-10 insulation to 4-ft depth along the slab edge saves about 3\% annual energy and reduces annual fuel cost by between 1 and $2 \%$. The energy savings vary slightly depending on the insulation configuration and building type. Although the current installation practice in Montana does not extend the interior footing insulation to the top of the slab, based on empirical data, this study concludes that irrespective of the insulation installation configuration, Montana buildings will save energy by insulating the slab edge with R-10 insulation to a depth of $4 \mathrm{ft}$. The payback period could vary from 4 years for small retail commercial buildings to 12 years in small office buildings. 


\section{References}

J.J.Hirsch \& Associates. 2006. eQUEST Version 3.6.( http://www.doe2.com )

NorthWestern Energy Corporation, October 2006. Fuel Heating Cost Comparison.

( http://www.northwesternenergy.com/documents/FuelHeatingCostComparisonOct06 )

Oak Ridge National Laboratory. 1991. Builder's Foundation Handbook. ORNL/CON295, Oak Ridge, Tenneessee. 